\title{
Mammograms in cosmetic breast surgery
}

\author{
M. A. Shiffman \\ 1101 Bryan Avenue, Suite G Tustin, California 92780.
}

Address for correspondence: Melvin A. Shiffman, 1101 Bryan Avenue, Suite G Tustin, California 92780.

E-mail: shiffmanmdjd@comcast.net

\section{ABSTRACT}

Mammograms are necessary as preoperative preparation for breast surgery in certain patients. There is a definite need for mammograms preoperatively in patients over 40 who should be obtaining mammograms on an annual basis. Under the age of 40 mammograms are up to the discretion of the surgeon. Postoperative mammograms should be obtained as a baseline 6-12 months after breast surgery.

\section{KEY WORDS}

Mammograms, Cosmetic Surgery, Breast

\section{INTRODUCTION}

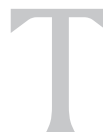

he use of preoperative and postoperative mammograms in cosmetic surgery has never been standardized. There appears to be some consensus that at least preoperative mammograms should be obtained according to the recommendations of the American Cancer Society for screening mammography. Women should begin monthly self-breast examination at age 20, clinical breast examination every 3 years from age 20 to 39 , and annual mammogram and clinical breast examination starting at age $40 .^{1}$

\section{PREOPERATIVE MAMMOGRAM}

The purpose of a preoperative mammogram is to detect any significant disorder of the breast(s) prior to cosmetic surgery so that the problem can be resolved before surgery or during surgery. Also, the mammogram is a baseline for detecting abnormalities after the cosmetic surgery.

The incidence of new breast cancer cases is increasing at a yearly rate and was estimated to be 203,500 in $2002^{2}$ and

\section{1,300 in 2003 in the United States. ${ }^{3}$}

It is essential to detect an early cancer so that cosmetic procedures of the breast do not cut across, distort, diminish the opportunity for cure, or limit the usefulness of lumpectomy in the treatment of the cancer. Breast cancer is now being detected, through the use of mammograms, earlier in the development of the tumor, at a smaller size, and with a better prognosis for cure.

The detection of a fibroadenoma is significant since carcinoma may occur within the fibroadenoma. ${ }^{4-10}$ The average age for fibroadenoma is 23 while the average age for carcinoma in the fibroadenoma is $43 .{ }^{4} \mathrm{~A}$ new tumor (fibroadenoma) after age 35 should be biopsied (most commonly with stereotactic needle biopsy). Under age 35 a fibroadenoma would need to be biopsied or excised if it continues to grow.

The 18 to 40 year old patient is the most commonly debated age group concerning whether or not to perform preoperative mammograms. This age group has not had a high incidence of breast cancer but presently has a higher 
incidence than previously reported because of earlier diagnosis. The average breast cancer tumor size in the author's practice was $3.0 \mathrm{~cm}$ from 1964 to 1985 and from 1985 to 2004 it was $2.0 \mathrm{~cm}$ showing that earlier diagnosis was being made through mammographic screening methods and better patient awareness of the need for regular examinations. Breast cancer has been reported in patients under the age of $30 .{ }^{11}$ The youngest patient with cancer seen by the author was 16 years of age. An argument by the radiologist has been that the youthful breasts have marked dysplasia on mammogram that prevents the detection of some abnormalities. Possibly by increasing the radiation to eliminate some of the dysplastic changes, a mammogram can be performed that will then focus on architectural distortion and calcifications.

Patients with a significant family history of breast cancer should begin to have annual mammograms 10 years before the youngest age of the individuals with the cancer. If a patient with a significant family history desires breast augmentation, then the patient must be forewarned of the problems of the implant possibly reducing the chance of early detection of cancer ${ }^{12}$ and consideration given to placing the implants beneath the pectoralis major muscle.

\section{POSTOPERATIVE MAMMOGRAMS FOLLOWING COSMETIC BREAST SURGERY}

Following cosmetic breast surgery, routine mammograms (6 to 12 months postoperatively) help to formulate a baseline for the future detection of breast cancer. Surgery involving the breasts can result in architectural distortion from scars and calcifications.

\section{COSMETIC SURGERIES}

\section{Breast augmentation}

The insertion of implants through areola or periareola incisions usually involves dissection through the breast tissues that can result in architectural scars within the breast tissue. Axillary, inframammary, and umbilical approaches do not usually breach the breast tissue itself. Calcifications have been reported in the fibrous capsule (around the implant) but do not resemble the calcifications seen with breast cancer. ${ }^{13-18}$ For implants in place for more than 12 years, $52.5 \%$ of those ruptured showed calcification but only $10.0 \%$ of intact implants showed calcification. ${ }^{14}$

Fat transfer into the breast parenchyma is no longer performed. ${ }^{19}$ The fat for augmentation is now injected beneath, into, and above the pectoralis muscle, although the patient should be forewarned of the possibility of inadvertent injection into the breast itself. The calcifications around a fat cyst are easily diagnosed as benign. ${ }^{20}$ Stippled calcifications of fat necrosis following fat injection appear circular and smooth and can be distinguished by an experienced mammographer from calcifications found with cancer. If there is any question, the calcified area can be sampled through stereotactic needle biopsy under local anesthesia.

Kinoshita ${ }^{21}$ stated that in some Magnetic Resonance (MR) findings of fat necrosis it was difficult to distinguish benign from malignant lesions. Kurtz et $\mathrm{al}^{22}$ studied Magnetic Resonance (MR) findings in patients with fat necrosis and found that all of the15 fat necrosis (FN) displayed fatisointense signal on T1-weighted and on proton-weighted, fat-suppressed sequences. They were delineated by more or less wide rim of low signal intensity with sharp border to the center. After intravenous injection of gadopenetate dimeglumine, they showed no increase in signal intensity in the center and no increase, or a minor increase, of the rim. Ultrasound could not distinguish FN from recurrent tumor in 6 cases although 7 looked like atypical cysts. MRmammography was felt to be a promising method for diagnosis of FN.

Bilgen et $\mathrm{al}^{23}$ studied 126 fat necrosis lesions in 94 patients. They found on mammogram radiolucent oil cyst (34 or $26.9 \%$ ), round opacity ( 16 or $12.6 \%$ ), asymmetrical opacity or heretogenicity of the subcutaneous tissues (20 or $15.8 \%$ ), dystrophic calcifications (5 or $3.9 \%$ ), and suspicious spiculated mass (5 or $3.9 \%$ ). Follow-up mammograms showed curvilinear calcifications in five, decreased density in 6 rounded opacities with another 2 disappearing, 11 dystrophic calcifications became more coarse, 6 of the asymmetrical opacities became vague and one developed an oil cyst and coarse calcifications, and 1 spiculated mass developed a small radiolucent oil cyst in the center. On sonogram the lesions were solid in 18 (9.5\%), anechoic with posterior acoustic enhancement in 21 (16.6\%), anechoic with posterior acoustic shadowing in 20 (15.8\%), cystic with internal echoes in $14(11.1 \%)$, cystic with mural nodule in 5 (3.9\%), increased echogenicity of the subcutaneous tissues in 34 (26.9\%) and normal in 14 (11.1\%). Follow-up ultrasound showed 18 of the 29 that had increased subcutaneous tissue echogenicity turned back to normal while in the remaining 11 small cysts formed. In the 19 solid appearing 
masses, 15 showed decrease in size while 4 remained stable (biopsy disclosed fat necrosis). The four complex masses showed increase in size and appeared more cystic. It was concluded that knowledge of the mammographic and ultrasound appearance of fat necrosis and evolution of these patterns may enable imaging follow-up and reduce the number of biopsies.

\section{Breast reduction}

In breast reduction there is cutting into and removal of areas of breast tissue that may result in significant scarring, architectural distortion, and calcifications, usually from fat necrosis. ${ }^{24}$ Miller et $\mathrm{al}^{25}$ noted that after reduction mammoplasty, all patients are left with a linear scar between the nipple and inframammary fold that accounts for the frequent finding of skin thickening of the lower breast. Fat necrosis presents as an irregular calcified mass. Brown et $\mathrm{al}^{26}$ noted that asymmetric densities were present in approximately half the patients. Parenchymal calcifications were apparent in $50 \%$ of patients after 2 years. Four out of 42 patients had biopsies for suspicious densities, which were benign on pathology.

Abboud et $\mathrm{a}^{27}$ have reported that breast reduction using liposuction has been associated with calcifications from fat necrosis. Sixty patients, with breast reduction, 34 with and 26 without liposuction were studied. There was a 6-30 month follow-up and calcifications were noted in $11 \%$. Deep intraparenchymal calcifications were more frequent after liposuction and most ( 5 of 7 ) were macrocalcifications. None could be confused with malignant calcifications because they were more scattered, more regular, and less numerous. If there is any question as to the cause of the calcifications, stereotactic needle biopsy should be performed. Alterations in breast tissue resulting from the use of UAL were a thickened dermal undersurface, markedly thickened vertical collagenous fibers, intact lymphatic vessels, and intact blood vessels. ${ }^{28}$

The use of ultrasound-assisted liposuction for breast reduction has not been found to be injurious to the breast tissue but still may be associated with calcifications..$^{29,30}$

\section{Mastopexy}

Breast lift (mastopexy) does not usually disturb the breast parenchyma unless there is some breast tissue reduction. The lift is mainly a skin reduction with release of the breast from the underlying muscle to reorient the breast into a higher position.

\section{Results from our series}

For the past 300 cosmetic breast surgery cases (breast augmentation, breast lift, breast reduction) the author has performed preoperative mammography on all the patients (age ranges from 18 to 58). There were two (2) cases of positive findings on mammography.

1. Age 18 for breast augmentation: bilateral diffuse small calcifications found on mammography. This was needle biosied and diagnosed as fibrocystic disorder. Surgery was changed from above the muscle for the implant to below the pectoralis muscle. This was to allow better visualization of the calcifications following surgery. She has been followed now for 3 years and has had no change in the calcifications.

2. Age 42 for breast reduction: Mammography showed grouped microcalcifications that was found to be carcinoma in situ on needle biopsy. Local resection was performed and the breast reduction surgery canceled. She was followed for two (2) years with mammography and then found to have a small invasive carcinoma in the same breasst quadrant as the prior carcinoma in situ. The patient elected to have bilateral mastectomy.

Post surgery mammography in these 300 cases showed one patient (age 55) with two (2) areas of grouped stippled calcifications in one breast one (1) year after McKissock type of breast reduction. Stereotactic needle biopsy showed benign disease (fat necrosis).

\section{DISCUSSION}

Preoperative mammograms are a screening technique to detect abnormalities before performing cosmetic surgery. There is some argument that cosmetic surgery is an elective procedure being performed on a healthy patient and there should be a more detailed workup with mammography to protect the patient even in the young age group before breast surgery. This would mean that every patient, no matter what age, should have a preoperative mammogram. ${ }^{31}$ Peras $^{32}$ reported that in 1149 cases of cosmetic surgery, early diagnosis of breast cancer was possible in 34 cases by the use of mammography. He strongly recommended that a policy of mandatory preoperative mammography be implemented so that all patients can be protected from a potentially lethal disease by early detection.

It is the surgeon's choice whether to order a preoperative mammogram prior to cosmetic breast surgery on a patient under the age of 40 , however, it has been recommended 
that all patients obtain a mammogram prior to breast augmentation. ${ }^{33}$ Patients who refuse preoperative mammography, if under the age of 40 , may safely be operated upon but the refusal should be noted in the medical record. This will help to protect the physician if there is future litigation. It is also the physician's choice whether to do cosmetic breast surgery on a patient over the age of 40 who refuses a preoperative mammogram. The patient should be fully informed of the possible consequences of missing a significant abnormality.

Postoperative mammograms will protect the patient by obtaining a baseline for future reference. The Eklund ${ }^{34}$ maneuver allows better visualization of the augmented breast and should be used routinely in postoperative augmentation mammograms. However, there are many patients who do not come back to the surgeon for follow up mammography because they feel fine and do not wish to be bothered with the procedure or the cost. This would require the surgeon to document in the medical record that the postoperative mammogram had been requested.

The patient who has a significant family history of breast cancer should be counseled on the possibility of future breast cancer and the possible need for genetic testing prior to any cosmetic procedure on the breast. If genetic testing is positive for BRCA1 or BRCA2, there is a $50 \%$ - $90 \%$ lifetime risk of developing breast cancer. ${ }^{35-38}$ If the genetic abnormality is present, there are a variety of early detection and prevention programs available. ${ }^{39}$ Patients at any age with a significant family history should have a mammogram before any cosmetic breast surgery is contemplated. The problems of early diagnosis of breast cancer that may be present if augmentation mammoplasty or any other cosmetic procedure of the breast is performed should be thoroughly explained prior to making any decisions about surgery.

\section{REFERENCES}

1. Smith RA, Cokkinides V, von Eschenbach AC, Levin B, Cohen C, Runowicz CD, Sener S, Saslow D, Eyre HJ. American Cancer Society guidelines for the early detection of cancer. CA-A Cancer J Clin 2002;52:8-22.

2. Jemal A, Thomas A, Murray T, Than M. Cancer statistics, 2002. CA - Cancer J Clin 2002;52:23-47.

3. Jemal A, Murray T, Samuels A, Ghafoor A, Ward E, Thun MJ. Cancer statistics, CA - Cancer J Clin 2003;53:5-26.

4. Durso EA. Carcinoma arising in fibroadenoma: A case report. Radiology 1972;102:565.

5. Buzonowsaki-Konakry K, Harrison EG, Payne WS. Lobular carcinoma arising in fibroadenoma of the breast. Cancer
1975;35:450-6.

6. Azzopardi JG. Problems in Breast Pathology, Philadelphia, W.B. Saunders 1979

7. Pick PW, lossifides IA. Occurrence of breast carcinoma within a fibroadenoma. A review. Arch Pathol Lab Med 1984;108:590-4.

8. Schnitt SJ, Connolly JL. Pathology of benign breast disorders. In: Harris JR. editor. Diseases of the Breast, $2^{\text {nd }}$ edn. Philadelphia, Williams \& Wilkins 2000. p. 75-93.

9. Botta PG, Cosimi MF. Breast lobular carcinoma in a fibroadenoma of the breast. Eur J Surg Pathol 1985;11:283-5.

10. Diaz NM, Palmer JO, McDivitt RW. Carcinoma arising within fibroadenomas of the breast. A clinicopathologic study of 105 patients. Am J Clin Path 1991;95:614-22.

11. Tabbane F, el May A, Hachiche M, Bahi J, Jaziri M, Cammoun M, Mourali N. Breast cancer in women under 30 years of age. Breast Cancer Res Treat 1985;6:137-44.

12. Silverstein HJ, Handel N, Gamagami P, Waisman JR, Gierson $\mathrm{ED}$, Rosser RJ, et al. Breast cancer in women after augmentation mammoplasty. Arch Surg 1988;123:681-5.

13. Peters W, Smith D, Lugowski S, Pritzker K, Holmyard D. Calcification properties of saline-filled implants. Plast Reconstr Surg 2001;107:356-63.

14. Peters W, Pritzker K, Smith D, Fornasier V, Holmyard D, Lugowski $\mathrm{S}$, et al. Capsular calcification associated with silicone breast implants:incidence, determinants, and characterization. Ann Plast Surg 1998;41:348-60.

15. Peter W, Smith D. Calcification of breast implant capsules:incidence, diagnosis, and contributing factors. Ann Plast Surg 1995;34:8-11.

16. Schmidt GH. Calcification bonded to saline-filled implants. Plast Reconstr Surg 1993;92:1423-5.

17. Young VL, Bartell T, Destouet JM, Monsees B, Logan SE. Calcification of breast implant capsule. South Med J 1989;82:11713.

18. Nicoletis C, Wlodarczyk B. A rare complication of breast prosthesis:Calcification of the periprosthetic retractile capsule. Ann Chir Plast Esthet 1983;28:388-9.

19. Fulton JE. Breast contouring with "gelled" autologous fat:A 10year update. Int J Cosm Surg Aesthet Derm 2003;5:155-63.

20. Rocek V, Rehulka M, Vojacek K, Kral V. Fat necrosis of the breasts with ring calcification. Acta Univ Palacki Olomuc Fac Med 1982;102:143-7.

21. Kinoshita T, Yashiro N, Yoshigi J, Ihara N, Narita M. Fat necrosis of breast:a potential pitfall in breast MRI. Clin Imagine 2002;26:250-53.

22. Kurtz B, Achten C, Audretsch W, Rezai M, Zocholl G. MR mammography of fatty tissue necrosis. Rofo Fortschr Geb Rontgenstr Neuen Bildgeb Verhfahr 1996;165:359-63.

23. Bilgen IG, Ustum EE, Memis A. Fat necrosis of the breast:clinical, mammographic, and sonographic features. Eur J Radiol 2001;39:92-9.

24. Baber CE, Libshitz HI. Bilateral fat necrosis of the breast following reduction mammoplasties. Am J Roent ;1977;128:508-9.

25. Miller CL, Feig SA, Fox JW. Mammographic changes in reduction mammoplasty. Am J Roent 1987;149:35-8.

26. Brown FE, Sargent SK, Cohen SR, Morain WD. Mammographic changes following reduction mammaplasty. Plast Reconstr Surg 1987;80:691-8.

27. Abboud M, Vadoud-Seyedi J, De May A, Cukierfajn M, Lejour M. Incidence of calcifications in the breast after surgical reduction and liposuction. Plast Reconstr Surg 1995;96:620-6.

28. Di Giuseppe A. Ultrasound-assisted liposuction for breast reduction. In: Shiffman MA, Di Giuseppe A, editors. Textbook of Liposuction: Principles and Practice. Marcel Dekker; 2004. 
29. Lejour M, Abboud M. Vertical mammoplasty without inframammary scar and with liposuction. Perspect Plast Surg 1990:4:67.

30. Lejour M. Reduction of large breasts by a combination of liposuction and vertical mammoplasty. In: Cohen M. editor. Master of Surgery:Plastic and Reconstructive Surgery. Boston, Little, Brown:1994

31. Jackson R. Personal communication. 2003

32. Perras $C$. Fifteen years of mammography in cosmetic surgery of the breast. Aesthetic Plast Surg 1990;14:81-4.

33. Lind DS, Copeland EM. III: Local recurrence, the augmented breast, and the contralateral breast. In: Bland KI, Copeland EM III, editors. The Breast:Comprehensive Management of Benign and Malignant Diseases. 2nd edn., Philadelphia: W.B. Saunders Company; 1998. p. 1421-32.

34. Eklund GW, Busby RC, Miiller SH, Job JS. Improved Imaging of the augmented breast. Am J Roentgenol 1988;151:469-73.

35. Taucher S, Gnant M, Jekesz R. Preventive mastectomy in patients at breast cancer risk due to genetic alterations in the BRCA1 and BRCA2 gene. Langenbecks Arch Surg 2003;388:3-8.

36. Winer EP, Morrow M, Osborne CK, Harris JR. Malignant tumors of the breast. In: DeVita VT, Hellman S, Rosenberg SA, editors. Cancer: Principles \& Practice of Oncology. Philadelphia: Lippincott Williams \& Wilkins; 2001. p. 1651-717.

37. Ford D, Easton D, Bishop Narod SA, Goldgar DE. Risks of cancer in BRCA1 mutation carriers. Breast Cancer Linkage Consortium. Lancet 1994;343;692-5.

38. Struewing JP, Hartge P, Wacholder S, Baker SM, Berlin M, McAdams $M$, et al. The risk of cancer associated with specific mutations of BRCA1 and BRCA2:among Ashkenazi Jews. N Engl J Med 1997;336:1401-8.

39. Grann VR, Panegeas KS, Whang W, Antman KH, Neugut Al. Decision analysis of prophylactic mastectomy and oophorectomy in BRCA1-positive or BRCA2-positive patients. J Clin Oncol 1998;16:979-85. 